\title{
Chapter 8 \\ Industrial Relations and Works Councils in the Netherlands-Results from Interviews and a Survey among HR Managers
}

\author{
Aukje Nauta
}

\subsection{The Context: Industrial Relations in the Netherlands ${ }^{1}$}

The Dutch labor market is growing more and more flexible. Over $10 \%$ of the workers are currently self-employed, whereas this percentage used to be $7 \%$ in 2001 (cbs.nl). Being self-employed is not a free choice for all workers, especially not for those who lack assignments and therefore income - the so-called outsiders on the labor market. Outsiders are also those workers who would like to have a permanent job, but can only get a temporary one. New and positive ways of flexible working are the so-called new working arrangements, in which employees work 'any place, any time'. These and other developments have a high impact upon industrial relations in the Netherlands.

Many criticizers of today's Dutch employment relations believe that new arrangements are necessary, in order to close the gap between insiders and outsiders on the Dutch labor market. To do so, Dutch government, together with the 'social partners' (trade unions and employer organizations) negotiated a 'social agreement' in 2013, in which they made all kinds of arrangements to improve sustainable employability, job transitions, as well as transitions from unemployment to paid work.

In this chapter, we will describe and illustrate developments such as above in the current Dutch industrial and employment relations. Next, we will describe the results of an interview study among ten HR managers of diverse Dutch organizations, about their perceptions of employee participation within their company, as it takes shape through the works council. Finally, results of a survey among HR managers on employee participation are described.

Employment relations are highly diverse in the Netherlands of today, ranging from the temporary worker who works only for 1 day during an event that she has

\footnotetext{
${ }^{1}$ This chapter is strongly based upon the first chapter of Nauta (2011). Tango op de werkvloer. Een nieuwe kijk op arbeidsrelaties. [Tango on the shop floor. A new view on employment relations.] Assen: Van Gorcum.
}

\footnotetext{
A. Nauta $(\bowtie)$

University of Amsterdam, Amsterdam, The Netherlands

e-mail: a.nauta@uva.nl 
to cater, to the civil servant who expects to work for another 15 years at the same municipality, until he turns 67 . From bankers who strive for ever-increasing bonuses and hop from employer to employer, to employees who feel very loyal to one organization for years and years. From highly educated management trainees who have and expect high-quality development opportunities, to machine operators who perform the same routine job for years and years. From caregivers who do what they are told by their bosses, to knowledge workers who craft their own job. Moreover, jobs are constantly changing, not only their content, but also regarding the contract. Due to technological developments, jobs appear and disappear with a much higher speed than a decennium ago. As a consequence, employers find it hard to employ people in permanent jobs. And even if people have a permanent job, it is not as stable as it used to be, before the economic crisis that started in 2008. Although the economy of the Netherlands within Europe is relatively stable and considered relatively strong, the unemployment rate has reached an all-time high of $8.8 \%$ in February of 2014 (cbs.nl).

There are a lot of so-called "outsiders" on the Dutch labor market, such as unemployed people, people with disabilities, lowly educated people who are forced to hop from one lowly paid temporary job to another. Much unemployment is "hidden": an estimated 1.2 million Dutch people wanted to work in the third quarter of 2013 - which is $11 \%$ of all people between 15 and 65 years (cbs.nl) - but cannot find a job due to their disability, chronic illness, age, or simply because their unemployment status makes employers believe that they are unfit for work. Muffels and Wilthagen (2011) show that lowly educated temporary workers get paid $35 \%$ less compared to workers in permanent jobs, even after controlling for age, education, gender, sector and duration of one's employment contract.

In the Netherlands, the legal arrangement of the employment contract is already more than 100 years old. Legal job arrangements were very simple and short until the Second World War (Jacobs et al. 2009). Over a century ago, labor used to be very clearly defined, because only a couple of hundred thousands of people were employed. The remaining people were self-employed. After World War II, the Dutch welfare state arose, and so did the legal arrangement of the employment contract, including laws on dismissal.

Today, many Dutch employers perceive labor law, including collective labor agreements (CLA's), as too complex and rigid, especially compared to the UK and the US. Employers are searching for ways out, for example by contracting temporary self-employed workers. Especially in the construction sector, many employers contract self-employed workers, in order to work flexibly and efficiently. By using temporary contracts, franchising, outsourcing, and pay rolling, employers reduce labor costs.

Dutch employment relations on the shop floor are embedded in a collective system of industrial relations. Decisions made by social partners and/or government have consequences for policies on lower aggregation levels, such as sectors and organizations. Decisions made at these so-called meso-levels have an impact upon behavior on the shop floor. For example, many employees above the age of 55 years are used to ask each other 'how many more years they have to work, until 
Table 8.1 The Dutch 'Building of Employment Relations' (Nauta 2011)

\begin{tabular}{|c|c|c|}
\hline & Forms of dialogue & Outcomes \\
\hline Fourth floor & European social dialogue & EU-directives \\
\hline Third floor & $\begin{array}{l}\text { Government, trade unions and employer } \\
\text { organizations }\end{array}$ & Laws, central agreements, advises \\
\hline Second floor & $\begin{array}{l}\text { Sectors, companies, unions and employer } \\
\text { organizations bargain for collective } \\
\text { agreements }\end{array}$ & Collective agreements \\
\hline First floor & $\begin{array}{l}\text { Management, HRM and works council } \\
\text { make HR policies }\end{array}$ & $\begin{array}{l}\text { Human resources management } \\
\text { policies and practices }\end{array}$ \\
\hline Ground floor & $\begin{array}{l}\text { Dialogue and negotiations between indi- } \\
\text { vidual employees and their superior }\end{array}$ & $\begin{array}{l}\text { Agreements about time, money, } \\
\text { performance and development }\end{array}$ \\
\hline
\end{tabular}

retirement'. This 'habit' is a consequence of all (pre-)pension arrangements in the Netherlands that became normal during the eighties and nineties. It is only since recent years that retirement age is increasing again, due to new laws that prohibit pre-pension arrangements.

Nauta (2011) uses a metaphor for the way in which Dutch employment relations are institutionalized and regulated: the so-called 'Building of Employment Relations' (see Table 8.1). This 'building' has five 'floors', ranging from the micro-level of employment relations at the shop floor, to the macro-level of industrial relations at the European level.

On the fourth floor, you will find the European social dialogue, which is currently gaining importance. This social dialogue refers to discussions, consultations, negotiations and common activities performed by European employer organizations and trade unions. Some of these consultations are bipartite (only employer organizations and trade unions), others are tripartite (with the EU also at the table). At europa.eu, you can find common documents of European social partners, as well as reports on industrial relations in Europe. For example, there is a social dialogue toolkit with recommendations to social partners who want to negotiate fair working conditions. Furthermore, there are European directions - a legal instrument of the EU, such as the direction on informing and consulting employees (Direction 2002/14/EC). This direction states that employers need to have arrangements for informing and consulting their personnel, fitting national laws and industrial relations. Information and consultation should be about economic, financial and strategic developments, as well as employment developments and decisions that result in large changes in the work force or contractual employment relations. Moreover, this EU-direction states that employer and ERs should work together in a cooperative atmosphere, in which they pay attention to each other's rights and obligations. Given the open economy and the many multinational companies present in The Netherlands, this European level is important.

On the third floor of the Dutch Building of Employment Relations, you will find the tripartite and bipartite structures of consultation between employer organizations, trade unions and sometimes also the Dutch Government. For example, these three partners negotiated the 'Social Agreement' in 2013, in which they took 68 measures to improve the functioning of the Dutch labor market. Specifically, the 
Netherlands has two institutions, the Social and Economic Council (SER), in which employer organizations, trade unions and independent members negotiate advises to the Dutch government, as well as the Labor Foundation (STAR), in which employer organizations and trade unions negotiate short-term agreements.

The SER advises the government on a broad social-economic spectrum. The SER contains 11 representatives of employers, 11 from trade unions and 11 independent members, appointed by the Crown: these are social-economic experts who reflect the political field in the Netherlands. The STAR does recommendations to trade unions and employer organizations with regard to working conditions within companies and sectors. Next to that, there is consultation between the government and the social partners. Especially during tough times, they negotiate large agreements, such as the social agreement in 2013, the pension agreements in 2010, 2011 and 2013, and the reduction of pre-pension arrangements in 2003.

An important role on the second floor of the Building of Employment Relations is played by the CLA (Huiskamp 2003). CLA's are negotiated by professional negotiators that represent the employees and employers in a sector or company. These negotiations do not always run smoothly. Strikes are sometimes-but not very often, compared to other European countries - the consequence. Around 80\% (6.1 million) of the Dutch employees are covered by a CLA (ser.nl), but this differs between sectors. In relatively new sectors, such as business services and IT, there are few CLA's. But in traditional sectors such as manufacturing, construction and the central government, almost all employees are covered by a CLA. This is due to the many so-called branch CLAs in these traditional sectors: these are CLAs that apply to a whole branch - instead of to one company only. The Dutch law declares sector CLAs as generally binding for all employees within the specific sector that negotiated the CLA. Thanks to this law, a minority of non-committed employers cannot undermine arrangements that are negotiated by the majority. There are over 700 CLAs in the Netherlands, of which 200 are branch CLA and over 500 are company CLAs. Pay seems the most important topic of CLAs. However, CLAs contain much more arrangements, such as working hours, training and education opportunities, working conditions, employee benefits, opportunities for promotion, et cetera. More and more CLAs contain arrangements on employability and sustainability. The many arrangements that CLA-negotiators make, have led to extensive CLAs, with sometimes hundreds of pages.

On the first floor of the 'Dutch Building of Employment Relations', the employer (CEO and/or HR director), together with the works council, consult each other on organization policies, especially human resources management (HRM). The works council is an important tool for equalizing power relationships within the company. Without a works council, employers would be able to do whatever they like, even if it is against the interests of employees. The Dutch Law on the Works council (WOR) helps to equalize employment relations at the company level. This law requires companies with 50 or more employees to install a works council. The law exists since 1950, and has been changed a couple of times since then. The law is followed reasonably well: $71 \%$ of the Dutch firms with 50 or more employees has a 
works council (Visee et al. 2012). HR policies within companies consist of several rules, procedures, instruments and tools that complement the CLA. For example, most companies have practices concerning recruitment, selection, promotion, pay, performance assessment, individual options with regard to employee benefits, training and education, etcetera.

It is the ground floor - the shop floor-where employment relations take shape on a daily basis. Interpersonal behavior between employees and their superiors shape their mutual relationship. Employees and superiors talk to each other, negotiate, argue, and avoid each other sometimes. They have formal conversations, such as performance appraisals or career conversations. They have informal talks as well, often next to the coffee machine. Some conversations take place on the team level: so-called work meetings. Work meetings can be a supplement and/or a complement to formal employee participation, which takes place in formal works councils. Goodijk and Sorge (2005) distinguish between direct (work meetings) and indirect (works council) employee participation. During work meetings, employees have a direct voice with regard to team policies (but only if the team leader allows voice). Ideally, the institutions that shape industrial and employment relations, such as HRM, works councils, organizational strategies, CLAs, national agreements, and even European directives, are facilitating employment relations at the shop floor. Although this may seem obvious, it appears that negotiators at higher levels do not always realize which consequences their agreements have for the shop floor. For example, arrangements such as extra holidays for older workers may seem fair, but in practice, they often lead to decreasing employability of older workers. Hence, an open social dialogue between employers and ERs is important at all levels of the 'Building of Employment Relations', to discuss and foresee how specific measures will work out for behavior and practices at the shop floor within companies.

To give an example of the connections between the different levels of industrial and employment relations: in 2008 research has been performed to examine the effects of higher level decisions upon lower level practices in employment relations in the Netherlands (Beleidsdoorlichting Arbeidsverhoudingen 2008). During the autumn of 2002, national social partners recommended that pay should not increase more than 2.5\%. During national negotiations in 2003 and 2004, social partners agreed that pay should not increase at all. These central agreements worked out as intended. In 2005, pay increases as agreed upon in CLAs were the lowest in 20 years. The decreasing trend clearly started in 2002 and accelerated after the agreement in 2003. Hence, central negotiators do have an impact on actual practices, although de-central negotiators still have much latitude to negotiate branch or company CLAs. The Dutch Social and Economic Council as well as the Dutch Labor Foundation are also influential. Due to the unanimity of their advices and agreements, they appear to have an impact on daily work practices (Jaspers et al. 2010). Dutch employees feel relatively secure, thanks to the Dutch system of industrial relations and the high level of trust between employers and employees. Collective labor conflicts are seldom in the Netherlands (Van den Berg and Van Rij 2007). Per 1000 employees, there were on average only 5.7 working days per year lost due to 
industrial action in the period 2005-2009, which is much less than the average of the EU-25: 30.6 days.

The position of the works council is not very easy in many Dutch organizations. Research shows that a representative sample of Dutch employees and managers give a 6.4 and a 6.2 respectively on a scale of $1-10$ for their satisfaction with the works council, which is a sufficient, but not a very high grade. Fourteen per cent of the employees, and $19 \%$ of the superiors, believe that the works council supports them effectively in designing work and working conditions (Ten Have et al. 2007). This implies that both employees and managers doubt the usefulness and necessity of the works council. In some organizations, management and works council try to innovate in employee participation. For example, in a health care organization with 1600 employees, the CEO once called the works council 'outdated', because works council members only discussed rules and procedures instead of substantial issues. After his rather provocative statement, works council members started a process of innovation. Together with management, they designed a new employee participation structure. They replaced the works council by three bodies: first, a supervising council of seven employees. And second, an orchestrating team of four employees and the CEO. This team decides on issues that are relevant for employee participation processes. Third, they implemented temporary project teams that address specific themes, for example new housing. This innovation resulted in a culture change: more dialogue at all levels, less distance between top management and shop floor (Van der Meer and Smit 2010).

Ideally, in all organizations, employee participation functions as in the above example, with on-going dialogues between the three stakeholders of Dutch employment relations: management, works council and trade unions. Management represents the company's interests, the works council represents employees' interests mainly, and the collective employees' interests are represented by the trade unions (Sapulete 2013). Optimally, each party strives towards an integrative result with its own skills and responsibilities in the respectable fields. There is a good reason for the distinction between trade unions and works councils in the Netherlands. The members of the works council are chosen by employees and paid for by the employer. Therefore, the works council benefits from a good relationship with the employer, making it somewhat dependent. In contrast, due to its structure with independent union officials, the unions can afford to put pressure on the relationship with the employer (Nauta et al.2008).

To summarize, the Netherlands has highly institutionalized industrial and employment relations, as illustrated by the Dutch 'Building of Employment Relations', in which the works council plays an important role. Although Dutch industrial and employment relations are quite peaceful—very few strikes - a serious threat of Dutch industrial relations is the current flexibilization of the labor market. The gap between so-called insiders and outsiders on the labor market is growing. Dutch government and central social partners are currently trying to close this gap with several measures. However, it is in the companies themselves where policies and practices also have to change. The works council can play an important role in these so-called social innovations, for example by setting up practices to strengthen the 
sustainable employability of employees, and to open up the company for workers with difficult positions on the labor market (e.g. people with disabilities). This asks for open dialogue and constructive negotiations between management and works council. The next paragraph discusses some specific examples of social dialogue within Dutch companies.

\subsection{What Do Human Resources Managers Say? Conclusions Drawn from the Interviews}

\subsubsection{Overall Evaluation of Company Level Social Dialogue}

We interviewed ten HR managers of mostly large organizations, one intermediate and one small organization, carried out between February and October 2013. Interviews lasted for about one hour. Note that the results are specific for these ten organizations. They function as an illustration, but cannot be generalized to the overall Dutch system and practices of employee representation.

Overall, the HR managers appeared to be satisfied, and sometimes even very satisfied with the quality of the social dialogue with their ERs. Table 8.2 presents an overview of the general evaluations that the managers gave with regard to the company level of social dialogue.

Positive aspects that managers mentioned are: early involvement of works councils in decision making processes, works councils that are open and trustful, intense collaboration on specific projects such as employability, informal consultation, involving more employees than only works council members in decision making processes, and investments in innovations of social dialogue, such as tripartite dialogue on HR policies (employer, works council and trade unions).

However, employers see room for improvement as well. Specific issues that they mention are: works councils should contain diverse members, not only 'old white male', as to represent the workforce better; they should also contain more competent members, who are able to discuss strategic issues with management; social dialogue can sometimes be too time-consuming; current CLA's seem unfit for the more and more dynamic future of work; sometimes, tensions and competition occur between works councils and trade unions. One of the organizations seriously suffered from 'organizing' by one of the trade unions. Unions use this method to build networks of employees and involve them in strikes and confrontational campaigns against their employer. By doing so, they hope to reverse the trend of declining union membership. During the time that we interviewed this company, they suffered from strikes and confrontational campaigns.

Below are some specific examples of the quality of social dialogue, and how dialogue actually takes place between employers and works councils. 
Table 8.2 Overview of the general evaluations from managers in the interviews

\begin{tabular}{|c|c|}
\hline Company & Overall evaluation of company level social dialogue \\
\hline University 1 & $\begin{array}{l}\text { Employer perceives open debates with the works council, which is } \\
\text { involved as early as possible in decision-making processes. Employer } \\
\text { perceives the current works council as somewhat outdated: too little } \\
\text { diversity within the works council (mainly old white men), too little com- } \\
\text { munication between works council and employees (their rank and file) }\end{array}$ \\
\hline University 2 & $\begin{array}{l}\text { This employer has a constructive and open dialogue with the works coun- } \\
\text { cil, due to open attitudes of works council members, who are competent } \\
\text { and trusting. Informal signalling of potential problems is part of this } \\
\text { relationship }\end{array}$ \\
\hline Manufacturing 1 & $\begin{array}{l}\text { Employer and works council are very much on speaking terms, and are } \\
\text { collaborating intensively in a large project on sustainable employability } \\
\text { of workers. But sometimes dialogues are somewhat too informal and time } \\
\text { consuming, according to the employer }\end{array}$ \\
\hline Food and drinks 1 & $\begin{array}{l}\text { Employer informally consults the works council every week, which } \\
\text { builds a lot of trust. Employer continually strives for good employment } \\
\text { practices and sustainable employability for workers. However, employer } \\
\text { suffers from 'organizing strategies' of the trade unions }\end{array}$ \\
\hline Food and drinks 2 & $\begin{array}{l}\text { Employer is satisfied with the current dialogue between management and } \\
\text { works council, although he foresees a more cloudy future, due to employ- } \\
\text { ment arrangements (CLA and labor law) that are currently too inflexible }\end{array}$ \\
\hline Bank 1 & $\begin{array}{l}\text { Employer recently introduced a new representation model, in which more } \\
\text { employees are involved in employee participation, but spending less time } \\
\text { on it. All works councils support this new model, which illustrates a high- } \\
\text { quality social dialogue }\end{array}$ \\
\hline Bank 2 & $\begin{array}{l}\text { Employer is nationally known as one of the forerunners in 'co-creating' } \\
\text { collective labor agreements, in which many employees were involved. } \\
\text { Employer perceives opposing interests between works council and trade } \\
\text { unions, which sometimes hinders an effective tripartite social dialogue }\end{array}$ \\
\hline Energy 1 & $\begin{array}{l}\text { Employer believes in the value of employee participation, because it } \\
\text { improves the quality of strategic decisionmaking. However, he would } \\
\text { like to increase the current quality of the dialogue with the works council, } \\
\text { which is now too much focused on detailed, individual-employee-related } \\
\text { issues, instead of strategic topics }\end{array}$ \\
\hline Small Business 1 & $\begin{array}{l}\text { Employer perceives employee participation not as a right, but as an } \\
\text { obligation for employees. Employer experiences better firm performance } \\
\text { and more engagement, due to all employees (not only works council } \\
\text { members) being involved in strategic decision making }\end{array}$ \\
\hline Engineering 1 & $\begin{array}{l}\text { Employer has introduced a new form of social dialogue, in which the } \\
\text { board, trade union and works council are mutually responsible for social } \\
\text { policies. They strongly focus on "mature employment relationships", with } \\
\text { constructive dialogues between employer and ERs }\end{array}$ \\
\hline
\end{tabular}

For example, University 1 is currently involved in a process of seeking intensive cooperation with another university. Both universities organized a joint theme day where relevant policy topics were discussed. Key topics were identified and a program manager was appointed and mandated to structure the forthcoming co-operation. The program manager tried to characterize the cooperation by stating 
that the individual rights of each works council would still be maintained. This led to a successful cooperation with proud members of the involved works councils.

There is a lot of trust between the board and the works councils. In situations where I cannot completely oversee a certain decision, or where some information might be uncertain, the works council is willing to trust me that it will all turn out right (Director, University 2).

Manufacturing 1 has a long history of employee participation. One of their plants used to be an independent company, who was the very first company in The Netherlands that implemented a works council by the end of the nineteenth century-in 1878 to be specific. Up till now, there still exists a strong consultation culture in this company. The relationship between management and works council is good, although this tends to vary per subject. Their HR director states: 'Especially the central works council has high standards. Every odd year there is a competence development program for the works council in addition to on-going programs to improve meeting quality. Last year, there was a week in which a great range of social policies crossed the table'.

The works council in Manufacturing 1 is very early included in decision-making processes. For example, when the company was outsourcing one of its units, the works council was involved in every step. The secret parts were covered with a so-called non-disclosure agreement. And in case of organizational changes or layoffs, the works council is included in a very early stage, much earlier than the law requires.

Tension rises sometimes due to the internationalization of Manufacturing 1 . The Dutch way of employee representation is perceived as a hassle, leading to friction. American and Chinese managers do not understand the Dutch mentality about employee representation. However, as Manufacturing 1 is Dutch by origin and policies, foreign managers will have to adapt.

In Food and Drinks 1, an example of the good relationship between management and works council is a recent management replacement. For compelling business reasons, the board had to change the composition of the management within a certain division. A procedure like this has to be approved by the works council, within a 4 -week response period. It would have been tempting to bypass the works council. However, the works council agreed to a 1-week consideration under full embargo.

In Food and Drinks 2, members of the works council are engaged and committed to their task. They understand and respect organizational interests. For example: due to a centralization process, the financial unit that is currently located in a Dutch regional city will be moved to a city in Eastern Europe. The works council does not protest against this move although it leads to direct job losses. They rather see that their employer serves the remaining staff well and has a decent social plan. Management is constantly and informally in dialogue with the employees and the works councils. In this way, long advice trajectories are avoided and both parties have a direct say in the final solution.

Food and Drinks 2 has no culture of conflict. Over the last 10 years, no strikes or serious conflicts occurred. One example occurred some 6 years ago. It turned out that management and works council interpreted the collective labor agreement 
differently. This resulted in a discussion about working hours and lunch breaks for the employees working in the supply chain. Finally, the works council and the management came together to meet with the company committee, a kind of mediation committee. In the end, the only request of the employees was to have an undisrupted lunch break. The management agreed, although they demanded to closely monitor the situation and to be able to intervene if problems occurred.

Illustrative for the quality of social dialogue in Bank 1 is the hectic period in which this bank was in real crisis and had to merge with another bank. During the merger, the central works councils of both banks formed a delegation that - together-dealt with the merger successfully, thanks to frequent and open dialogues with the management. For the new long-term company strategy, management and works councils had workshops and sessions together, discussing the possible scenarios. The works council was involved with every step during 2 -weekly meetings. Two years ago, Bank 1 decided to downsize, but informed the works councils too late. Hence, they were not amused. To solve this conflict, management apologized, thereby preventing escalation of this conflict.

Bank 2 also experiences a good social climate. This bank recently established an open dialogue, focused on common interests related to the future of the company. This means that management involves ERs in decision-making and policy changes as soon as possible. Sometimes, conflicts arise, for example in 2013, when the works council complained that too many secretaries were made redundant. As tensions rose, the HR manager tried to find a common interest during a constructive dialogue. After a day of consultation, a manager-versus-support-staff ratio was agreed upon and established. This example shows how conflict between works council and management is dealt with within Bank 2.

Bank 2 is nationally known as a forerunner in "co-creating" (i.e. integrative bargaining) the collective labor agreement (CLA). Both employer and trade unions focused on common interests instead of distributive bargaining. Surveys and discussion panels among employees were held to learn about the main interests of employees. It appeared that they valued a lengthened redundancy plan over and above performance-related pay. These two preferences made it directly into the collective labor agreement.

The director of Energy 1 perceives that the works council is more qualified in formal processes and procedures than in dealing with strategic topics, which is due, first, to the low expertise of ERs, and second, to the hierarchical culture-people are used to do what they are told instead of taking initiatives.

In Small Business 1, dialogue between management and works council, and in fact with all of their 110 highly educated employees, is very open and frequent. Every quarter of a year, management meets with all employees to discuss current strategic issues, including financial figures. Besides that, this company has both a works council, which focuses upon formal and legal issues, and a 'Council of Contributors', that is involved in all policy issues - for example, the purchase of new company cars, or the implementation of new training programs. The CEO of this company perceives employee participation not as a right, but as an obligation, because this is a perfect way for employees to learn management skills. 
In Engineering 1, they installed a new form of employee participation, in which management, works council and trade unions work closely together in a 'tripartite steering group' that is responsible for employee development and other important social policies. Engineering 1 has run several pilots, organized by employees as members of temporary project groups, in order to improve and innovate in social policies (e.g. employability measures). Hence, Engineering 1 extends employee participation by not only having a works council, but having employees directly participate in policy-making as well-a process of social innovation, as they call it. The members of the tripartite steering group signed an agreement in which they stated that they have joint responsibilities to develop social policies that have the same legal status as the collective labor agreement. The remaining CLA could therefore be reduced to basic agreements on salary, insurance and other material matters.

According to the HR director of Engineering 1, the current employee representation practices operate very well. The works council said in their yearly evaluation: 'we have a fantastic working relationship with our employer, but not too close'. All policy topics are open for discussion between management and the works council, monthly financial forecasts included. During informal meetings, 'soft' but important topics such as culture, attitudes and behavior, and leadership are discussed, which builds mutual trust.

An incident happened during a pilot with flexible working at Engineering 1. The works council said: 'we want to use our right of consent for this pilot'. The management reacted: 'Then we will have to suspend, as we have agreed that in this process of social innovation, no permissions will be asked to either management, works council, or trade union. Instead, we previously agreed that the steering group should decide. If you wish to use a right of consent, you are withdrawing the pilot from the social innovation process, thereby undermining the whole social innovation process'. After a 15-min break, the works council gave up their right of consent but requested a consult with a specific manager instead. This consult took place and next, new ways of flexible working were introduced. The HR manager comments: 'This incident shows that social innovation, in which new forms of social dialogue are introduced, is not easy at all'.

In sum, the interviews show that social dialogue is quite constructive within Dutch organizations, at least within the ten companies in our sample. In general, HR managers have open dialogues with the works council, involve ERs early in the process of decisionmaking, trust them, and sometimes succeed in innovating the system of employee participation, especially by extending employee participation to all employees (direct participation) instead of formal employee representation only (indirect participation).

\subsubsection{Changes Desired by Employers}

Although in general, the HR managers that we interviewed were quite satisfied with the level of social dialogue with works councils, they also perceived room for improvement. For example, the HR manager of University 1 would like to see a less 
traditional mind-set amongst works council members, in which they do not merely stand up for acquired rights of employees, but are focused upon (social) innovation as well. The management of University 1 perceives the current form of dialogue with the works council as a bit outdated, due to too little diversity within the works council (mainly old white men), and too little communication between works council and employees. Management prefers an integration of the student council and faculty council, because the interaction between both stakeholders - students and employees - is likely to provide added value. Also, new technology could possibly provide more and faster communication with employees, making employee representation more efficient and providing more bottom-up feedback from followers.

University 2 would like to receive more macro-feedback from the works council. At this moment, the works council seems to be driven by what happens day to day and therefore focuses strongly on daily business and operations. The manager explains: 'Sometimes the works council complains about a copier being out of order, instead of focusing upon strategic issues'.

The management of Manufacturing 1 would prefer a structure of employee representation that would take less time and money, because in this company, too many employees are involved and too many dialogues are taking place on multiple tables, also informal ones.

At Food and Drinks 1, management does not complain about the works council, but all the more about their dialogue — or lack of it—with the trade unions. One of the managers that we interviewed said: 'I doubt whether the unions have achieved a lot for their members over the past years. We are willing to negotiate fair deals, but only if they go for dialogue instead of organizing employees to go on strike'. The management of Food and Drinks 1 aims at a constructive dialogue with all stakeholders in employment relations of this company. As the HR manager said: 'We strive for sustainable employability for all workers in our company, as well as for good employment practices. We therefore believe that "organizing" is not very helpful. It is destabilizing and highly political, and it can be questioned whether "organizing" indeed benefits the employees of this company'.

The HR director of Food and Drinks 2 is satisfied with the current dialogue, although he foresees a more cloudy future. 'The current crisis as well as the national social agreement that was recently 2013 negotiated by the national social partners will keep on testing the employment relations system, internationally and nationally, and it will also test this company. It will be a try-out time for tentative subjects such as the right of dismissal, flexible employment relations, and pensions. At this moment, we are having a good on-going dialogue with the trade unions, for example about the pension system. However, it looks as if the Netherlands is saying 'goodbye' to the current welfare state, which constrains room for win-win agreements, both at a national and at this company level'.

At Bank 1, they are gradually replacing their traditional model of employee participation for a more modern model, in which more employees will be involved in employee participation, but less of their working time. Specifically, $50 \%$ of the works council will consist of 'traditional' ERs another 50\% will consist of 
employees who perform only part-time tasks in their representative role, for example, ICT employees working on a specific ICT-related policy issue on which the works council has to advise or assent. This new model has a couple of advantages: more employees will be involved in employee representation; the works council will be a better reflection of the diverse workforce; and the works council can use specific expertise that will be helpful for the issues at hand. Other changes that Bank 1 wants to implement are: more use of social media by the works council as to involve employees better; more informal chats between management and employees; and obligatory membership of the works council for young management trainees.

At Bank 2, management sometimes perceives competition between works council and trade unions. For example, the works council is not involved in negotiating the collective labor agreement, whereas they prefer to be so. Furthermore, both works council and trade unions argue that "the other" is not representing the employees fully. This competition hinders an open tri-partite dialogue.

At Energy 1, management strongly believes that every employee-not only the works council-should have a voice. They are currently exploring possibilities to involve all employees, using modern social media technology. Moreover, they would like to increase the quality and expertise of works council members. 'Some people are in the works council for over 20 years, which hinders a constructive dialogue. We have to change that, according to management.

At Small Business 1, some people complain about what they call 'fake employee participation': 'In the end, management decides on everything'. However, management does their utmost to invest in indirect and direct employee participation. For example, employees can go for a walk with the CEO during lunchtime, and voice their ideas and worries.

At Engineering 1, management worries about employees being too satisfied. According to management, there are too many social safety nets for employees, affording them to lean back instead of being proactive in constantly improving their own work methods and voicing ideas for policy improvement at the company level.

In sum, although Dutch HR managers are quite satisfied with dialogue with their works councils, they also see room for improvement. Specifically, they would like to see more modern instead of traditional mind-sets amongst ERs, who could for example use new information technologies more often, such as social media to communicate with all employees. Furthermore, they would prefer employee representation that focuses on strategic issues, without taking too much time. Moreover, they foresee an ending of the current Dutch welfare state and luxurious safety nets for employees, which should be on the agenda of conversations between management and works council. And finally, the relationship between works council and trade unions constantly deserves attention, to have a fruitful tripartite dialogue between management, works council and unions. 


\subsection{Perceptions of Human Resources Managers on Employee Representatives. Results of the Survey}

Figure 8.1 shows the results of a survey among 614 European HR managers from 11 European countries. The answers of the 70 Dutch respondents are compared to all European respondents. Red circles refer to statistically significant differences.

The Netherlands appears to score on the European average with regard to 9 of the 17 variables. This means that with regard to relations between HR managers and ERs, Dutch HR managers, compared to European HR managers, perceive equally trustful industrial relations - as measured with items such as 'To what extent is there a trusting relation between management and employee representatives?'. They find ERs equally able. Related to this, Dutch HR managers perceive equally low levels of competitive conflict management by ERs, and they find ERs equally competent compared to Europe on average. Managers' need for control is also on an average European level. Furthermore, compared to Europe, Dutch HR managers perceive equally low levels of relationship conflict with ERs, measured by items such as 'How much personal friction is there between management and employee representatives?'. The impact that ERs have on traditional issues according to Dutch HR managers is also equally high compared to European HR managers, as appears to be the case with regard to conflict management efficacy and quality of agreements, as perceived by Dutch HR managers.

However, there are some differences as well between Dutch and European HRmanagers. On the positive side, Dutch HR managers perceive higher integrity of ERs

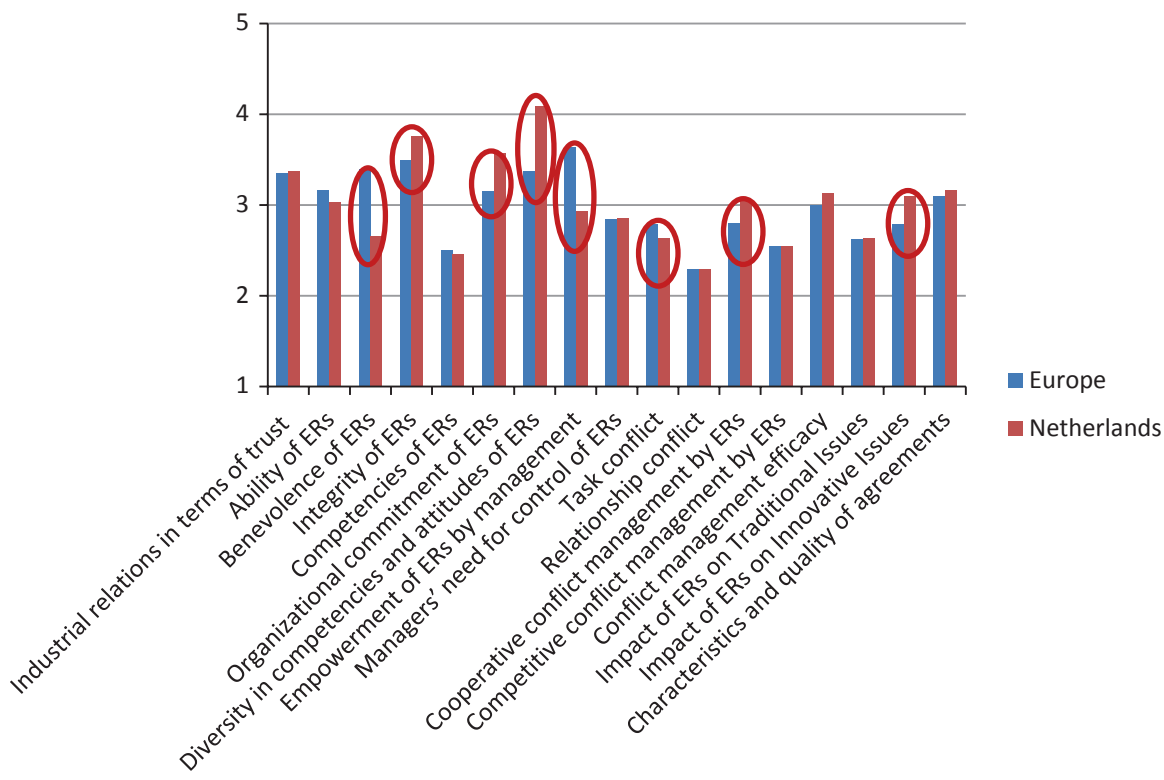

Fig. 8.1 Differences between The Netherlands and Europe on the variables in the survey 
$(M=3.76$ versus $M=3.47)$ and more organizational commitment of ERs $(M=3.57$ versus $M=3.16$ ). It appears that Dutch HR managers perceive significantly less task conflict with ERs than European HR managers ( $M=2.64$ versus $M=2.81)$, as measured with items such as 'To what extent do management and ERs disagree about the content of strategic decisions?'. Furthermore, more impact by ERs on innovative issues ( $M=3.10$ versus $M=2.80$ ) such as Corporate Social Responsibility and 'green issues'; more cooperative conflict management by ERs ( $M=3.05$ versus $M=2.76)$. Hence, the Dutch HR managers in our sample appear to be quite positive about the strategic position, attitude and behavior of ERs.

On the critical side, it appears that Dutch HR managers perceive their ERs as significantly less benevolent $(M=2.66$ versus $M=3.35)$ and less empowered by management $(M=2.93$ versus $M=3.61)$ than European managers. The Dutch perceive a relatively high level of diversity in competencies and attitudes of ERs ( $M=4.09$ versus $M=3.38)$, as measured by the item 'I see large differences between the employee representatives in my organization in terms of competencies and attitudes'. In other words, although Dutch HR managers perceive the ERs in their company as of high integrity, they do perceive them as relatively less benevolent compared to the average scores in our European sample. Apparently, Dutch HR managers accept that their ERs are sometimes their opponents, which might be a reason why Dutch HR managers score relatively low on empowerment of ERs by management. Most interestingly, Dutch HR managers perceive a relatively high level of diversity in competencies and attitudes of ERs. They believe that some ERs are quite competent and constructive in their role, but others are less so. This might make Dutch HR managers somewhat hesitant to take their works councils seriously.

In sum, the survey results appear to be in line with the interviews: Dutch HR managers appear to be relatively positive about their dialogue with works council members, also compared to HR managers in other European countries. The Dutch perceive relatively little task conflict with ERs, high integrity of ERs, cooperative conflict management by ERs, high impact of ERs on innovative issues (e.g. CSR), and high organizational commitment of ERs. However, Dutch HR managers are relatively less positive compared to the other European managers in our sample about their perceptions of both benevolence and empowerment of ERs; moreover, they perceive much diversity in competencies and attitudes of ERs.

\subsection{Conclusions and Recommendations}

To conclude, the Netherlands seems on the right track with regard to the quality of employee representation. However, just being satisfied with social dialogue is not enough, because there are currently serious threats to the Dutch labor market. Hence, we recommend (Dutch) works councils to become a real (competent, serious, constructive) partner in innovating and improving employment relations. This process starts with management, who has to take employee participation 
seriously. Luckily, innovation of employee participation is an important theme in the Dutch world of employee participation of today. For example, the Dutch journal Zeggenschap, which is the most-read professional journal for practitioners in the field of employee participation in the Netherlands, recently had a special series on renewal of employee participation (Audenaerde and Van de Hoeven 2013; Clark 2013; Nauta and Van Tienen 2014). Based on this series, and the current chapter, our recommendations are the following.

First, employee participation deserves to be extended to all employees, instead of formal ERs only. By doing so, employers will increase the level of commitment amongst their personnel, which is necessary due to the continuous change that is taking place within companies and on the labor market.

Second, improving social dialogue implies a process of continuous learning, experimenting and improving. This may also ask for new ways of learning employee representation skills. The Netherlands has a strong tradition of educating ERs. This tradition is maybe a bit too traditional, with ERs going to class for 2 or 3 days each year, learning all rules of the law on employee participation, but not so much the (political) games that they have to play. Due to increased flexibility and change, ERs should learn more by doing, and reflect upon doing their job, maybe with the help of so-called professional 'learning producers' (Nauta and Van Tienen 2014). By doing so, ERs can increase their skills, which will increase the chance that management will do serious business in open dialogues with them.

Open Access This chapter is distributed under the terms of the Creative Commons Attribution Noncommercial License, which permits any noncommercial use, distribution, and reproduction in any medium, provided the original author(s) and source are credited.

\section{References}

Audenaerde, M., \& Van der Hoeven, K. (2013). Medezeggenschap is van iedereen. [Employee participation belongs to everybody] Zeggenschap, 4, 24-25.

Beleidsdoorlichting Arbeidsverhoudingen. (2008). Policy screening on industrial relations. http:// docs.minszw.nl/pdf/35/2008/35_2008_3_12444.pdf. Accessed 1 Sept. 2014.

Clark, P. (2013). Nieuwe vormen van medezeggenschap. [New forms of employee participation.] Zeggenschap, 3, 36-38.

Goodijk, R., \& Sorge, A. M. (2005). Maatwerk in overleg: kiezen voor passende overlegvormen. [Customized consultation: Choose for consultation methods that fit.] Assen: Van Gorcum/ Stichting Management Studies.

Huiskamp, R. (2003). Arbeidsrelaties en onderneming: vernieuwing in theorie, empirie en praktijk. [Employment relations and enterprises: Renewal of theory, empirical results, and practice.] Utrecht: Lemma.

Jacobs, A. T. J. M., Massuger, P. M. M., \& Plessen, W. G. M. (2009). De arbeidsovereenkomst. [The employment contract.] Mon. BW B37. Deventer: Kluwer.

Jaspers, T., Van Bavel, B. J. P., \& Peet, J. (2010). SER, 1950-2010. Zestig jaar denkwerk voor draagvlak. [SER, 1950-2010. Sixty years of thinking aimed at getting support.] Amsterdam: Boom. 
Muffels, R. J. A., \& Wilthagen, T. C. J. M. (2011). Flexwerk en werkzekerheid in tijden van crisis. [Flexible work and employment security in times of crisis.] Economisch Statistische Berichten, 96(4602), 54-58.

Nauta, A. (2011). Tango op de werkvloer. Een nieuwe kijk op arbeidsrelaties. [Tango on the shop floor. A new view on employment relations.] Assen: Van Gorcum.

Nauta, A., \& Van Tienen, I. (2014). Klassieke scholing belemmert medezeggenschap. [Traditional education hinders employee participation.] Zeggenschap, 1, 4-6.

Nauta, A., Euwema, M., Krijger, L., Schoonhoven, R., \& Pehlke, B. (2008). Hoe ondernemings-raden hun rol beleven en uitoefenen. [How works councils perceive and execute their role.] Rotterdam: NCSI.

Sapulete, S. (2013). Works council effectiveness. Determinants and outcomes. Ridderkerk: Ridderprint. ISBN 978-90-816238-7-2.

Ten Have, C. J. M., Oeij, P. R. A., \& Kraan, K. O. (2007). Arbeidsvoorwaarden en arbeidsverhoudingen op ondernemingsniveau. [Working conditions and employment relations at company level.] Hoofddorp: TNO.

Van den Berg, N., \& Van Rij, C. (2007). Ervaringen van werkgevers met de cao en avv. [Experiences of employers with the CLA and the Statement of General Applicability.] (publicatie nr. 1529). Amsterdam: Regioplan.

Van der Meer, M., \& Smit, E. (Red., 2010). Medezeggenschap en organisatieontwikkeling. Vier scenario's in de praktijk. [Employee participation and organization development. Four scenarios in practice.] Assen: Van Gorcum.

Visee, H., Saalbrink, S., \& Mevissen, J. (2012). Naleving van de wet op de ondernemingsraden. [Compliance to the law on works councils.] Amsterdam: Regioplan. 